Revista Iberoamericana, Vol. LXVIII, Núm. 199, Abril-Junio 2002, 393-415

\title{
CINE Y REPRESENTACIÓN. POLÍTICAS DE LA VERSIÓN CINEMATOGRÁFICA. CINE/REALIDAD/LITERATURA. (EL CASO DEL POLICIAL LITERARIO EN EL CINE ARGENTINO)
}

\author{
POR \\ NÉstor Aguilera \\ Universidad Nacional de Córdoba \\ Carlos Gazzera \\ CEA-Universidad Nacional de Córdoba
}

El siguiente ensayo se propone analizar el fenómeno del cine dentro de un campo de problematizaciones que nos permitirán establecer algunas relaciones con el fenómeno literario. Dicho campo se articula a partir de tres ejes: el cine como representación (¿de la realidad o de lo real?); el cine como representación de una representación literaria políticas de la lectura (versión cinematográfica [vs.] adaptación); el policial como un género clave de la modernidad — lecturas políticas de lo social (un recorrido por las tradiciones literarias y fílmicas del policial desde la cultura argentina).

Proponemos comenzar pues con una serie de preguntas que quizás puedan ir demarcando mejor el perfil de este campo de problematizaciones. ¿Qué tipo de relaciones puede establecerse entre cine y literatura, más allá de la mera y tan mentada adaptación o trasposición de un lenguaje a otro? ¿Es el cine un lenguaje otro o, por el contrario, la puesta en crisis de todos los lenguajes, de la posibilidad misma de representación? ¿De qué manera el cine, en tanto producción simbólica, se relaciona con lo imaginario construyendo nuevos modos de percepción de lo real? En otras palabras, ¿de qué modo el mundo es alucinado por el cine?

\section{Cine/Literatura. Políticas de la Representación}

\section{I.1. Modernidad y vanguardias. Llega la peste}

Todos recuerdan — estamos seguros - esa escena de Un chien andalou, ${ }^{1}$ donde un hombre en el balcón (el propio Luis Buñuel) aparece, primero, afilando una navaja; luego, éste mira la luna llena y ve cómo una nubecita le corta su preñada redondez. Una mujer sentada en una silla parece externa a los movimientos del hombre y la nube. Sin embargo, pacífica, ella se presta a que él la rodee por detrás con su brazo, le sostenga los párpados y corte con la navaja su ojo haciendo saltar de esa perdida mirada una gelatina vidriosa.

${ }^{1}$ Un perro Andaluz, (1928) producida, escrita y dirigida por Luis Buñuel y Salvador Dalí, con la actuación de Pierre Batcheff, Simone Mareuil, Jaime Maravilles, Salvador Dalí y Luis Buñuel. Cabe recordar que el film es mudo, a pesar de que en 1927 aparece el cine sonoro. 
Esta secuencia, leída frente al resto del film, puede pensarse como un prólogo a la película, pero también un prólogo/manifiesto de su autor a toda su concepción del cine. Un cine que se resiste a la mirada realista de la realidad (por eso, Buñuel, que mira al mundo a través del ojo Cíclope de una cámara sabe, de entrada, que a la burguesía le está sobrando un ojo — el ojo de la falsa conciencia), en fin, que se niega a la fetichización del arte. Un cine que se piensa como resistencia al mercado. Por eso, quizá, el mismo Buñuel interpreta el papel de quien corta de raíz el mal que amenaza al cine. Como dijo alguna vez Dalí, "El mejor cine es el que puede verse con los ojos cerrados” (Grüner 174). ${ }^{2}$ Dalí, sin quererlo, anunciaba en el revés de su afirmación el sueño de un arte llamado a dar cuenta de la lógica del capitalismo neoliberal de un arte "global”, de un arte cuyo ejeHollywood es hoy un no-lugar.

Actualmente sabemos, incluso después de ver la filmografía del propio Luis Buñuel, que aquel corte fue un acto fundacional. No por transformar el cine. No. Se trató de un acto simbólico, donde la navaja de Buñuel imita y retoma a la vez la navaja de Occam. ¿Qué gesto? ¿Cuál es su renovación? Así como Occam corta con la “falange” del tomismo, narración capaz de explicar la manifestación divina en cada una de sus proposiciones, Buñuel aspira a que el cine no se convierta en una narración capaz de dotar de imágenes "noveladas” a la burguesía.

Desde este marco fundacional, donde el surrealismo se vuelve un espacio cohesionante de dos materiales culturales que nacieron juntos (el cine y el psicoanálisis tienen como fecha fundacional $1895^{3}$ ), nosotros intentaremos leer de qué modo el cine, como narración apropiada por los sectores culturales subalternos, ${ }^{4}$ tuvo en el género policial un espacio de estilización, donde la “comunidad imaginada” podía encontrar su lugar de enunciación.

En primer lugar cabe señalar que el cine, en tanto representación, surge como un arte nuevo que nacía de las entrañas mismas de la ciencia, de los sueños de la razón — que como Goya decía llegan a engendrar monstruos—, de la imaginación técnica, del desarrollo tecnológico y de la lógica misma del capitalismo. Era imposible pues no sentirse seducido por un arte que aparentemente venía a cumplir a la perfección con el viejo y aristotélico

${ }^{2}$ Es interesante comprobar que esta idea de Dalí es cercana a la idea del Borges ciego que aún sigue frecuentando el cine.

${ }^{3}$ En 1895 se registran las primeras proyecciones de los hermanos Lumière y se publica de Freud Proyecto de una psicología para neurólogos. Pero la relación no termina allí. Hay aún algo más que se registra en el "incosciente óptico" de la primera película proyectada por los hermanos Lumière. La salida de los obreros de las fábricas Lumière; allí la metáfora de unos obreros que salen de la fábrica y se "meten" en el cine. ¿ंNo hay aquí algo más que premonitorio, en el mismo año en que se funda en Francia la C.G.T., al señalarse el lugar que tal vez ocuparía el cine como distracción para las masas?

${ }^{4}$ Erwin Panofsky ha señalado como nadie que el cine, el séptimo arte, es la única manifestación artística cuyo origen es "genuinamente popular" y que su base ha sido funcional al placer de disfrutar una película. Pero Panofsky también ha señalado que el cine-arte en sus comienzos no fue narrativo. Para ello evoca de qué modo la gente se reunía en las cantinas o tabernas para disfrutar un "paisaje bonito" o una imagen conocida. A los primeros espectadores lo cautivaban las imágenes y no los relatos. Por ello Panofsky nos remite a cómo ese habla popular de las tabernas le impuso casi de inmediato la etimología de la imagen estática en el picture a esos frames proyectados en las paredes. Hoy cuando hablamos de movies no debemos olvidar que la transición nominal viene de movie picture. 
proyecto mimético del arte. Pero, paradojas de la modernidad, lo que el cine como arte vino a evidenciar desde su comienzo fue el carácter ilusorio de toda transparencia con la realidad. Y es que Sigmund Freud había introducido — simultáneamente a la aparición del cine-, en el centro mismo del sujeto cartesiano, el virus que desataría la peste": la aparición del inconsciente. ${ }^{5}$

Por otra parte, también ya Marx había inoculado su virus en la lógica económica del capitalismo y en los efectos ilusorios de la misma en el plano de la cultura. Es así como el cine, que tuvo su origen en la vanguardia científica, tecnológica, y luego estética y política, representó la puesta en crisis del concepto mismo de representación como reflejo transparente de la realidad: la realidad es siempre producida. Y es en tal sentido que el cine, denominado como esa máquina de producir sueños, puede aproximarnos a esa otra máquina de producir fantasmas que es lo inconsciente —según Lacan, la única realidad, lo propiamente real para el sujeto (1999). De allí la importancia del imaginario (y habría que decir, del fantasma) como ese registro de imágenes que hace posible metabolizar una impresión, tras lo cual se modifica a la vez el percepto. La industria del cine es —y más aún en esta fase del capitalismo denominada tardía — la industria de las imágenes que producen nuevos modos de percepción de lo social, cada vez más, a través de la fetichización de la cultura.

\section{I.2. Modernidad: una fábrica de monstruos}

¿Qué es el desarrollo del capitalismo sino la historia de la fetichización de la cultura? ¿Qué es esta afirmación — por lo pronto obvia— sino la persistencia de un anacronismo crítico tardío que supo iluminar, desde el marxismo y el psicoanálisis, lo mejor de la tradición crítica moderna de la cultura? Por eso hay una sucesión anacrónica (de afinidad) entre los monstruos de la razón de Goya y esa peste que anida en el inconsciente freudiano. Anacronismo que supo oponer un contra-tiempo (ana-chronos) a esa doxa de la Historia entendida como progreso, para poder cepillarla a contrapelo -como sugería Walter Benjamin-, de tal modo que pudiésemos hallar en el pasado aquellas imágenes que relumbran en el instante mismo de un peligro; aquel origen de los bienes culturales que no podrían ser contemplados nunca sin horror. Ésta es la metáfora de Buñuel en el inicio de Un chien andalou.

\section{LA TRANSPOSICIÓN COMO POLÍTICA DE LECTURA}

Los debates que se desarrollaron a lo largo del siglo veinte en torno al papel de la crítica y su concepción de una nueva teoría del arte —que superara las determinaciones de sus antiguos fundamentos ideológicos-, encuentran en el cine un lugar clave para su reformulación permanente, ya que el mismo introducirá un nuevo modo de organizar la

\footnotetext{
${ }^{5}$ Resulta más que ilustrativa la anécdota que rescata Grüner sobre la llegada de Freud a EE.UU.: "Se dice que Sigmund Freud, al llegar a Nueva York con un grupo de acólitos, y viendo la calurosa bienvenida que se le prodigaba, masculló unas palabras famosas. Inocentes. no saben que les traemos la peste" (150).
} 
percepción y, con él, modificará la concepción misma del arte, el cual ya no podrá pensarse al margen de sus determinaciones técnicas que hacen posible su producción/reproducción e imponen determinadas formas de percepción social, haciendo del fenómeno estético una problemática que es en sí misma política (Olivera 1996). En el caso particular de las adaptaciones cinematográficas de textos literarios, la relación cine/literatura instaura nuevamente, no sin conflicto, los puntos claves de esa misma problemática.

Cuando hablamos del traspaso (¿traspié?) de una obra literaria al cine estamos hablando de una representación de la representación, es decir, de una especie de metarepresentación, para la cual resulta imposible desentenderse de una reflexión sobre las posibilidades y limitaciones que un tipo de representación tiene para representar a otro. Es allí donde se hace necesario aclarar que estamos frente al problema, no de cómo se lleva a cabo el traspaso de una escritura literaria a un lenguaje visual cinematográfico, sino de cómo se lleva a cabo la representación de aquello que hace posible, en definitiva, al fenómeno mismo de la transposición: una lectura. ¿Cómo representar una lectura? Estamos ingresando pues al campo de la subjetividad y del imaginario, es decir, al campo de lo social, de lo histórico y de lo político.

En un texto - y de hecho una película lo es — donde se representa una lectura, el lector pasa a constituir una categoría más dentro de la estructura de ese nuevo relato en el que queda incorporado a partir de haber hecho ingresar su punto de vista como si se tratara de un nuevo personaje. Por más que Nabokov no pudiera salirse de su enojo, el personaje principal de Lolita resultaría ser un personaje que no se hallaba en sus papeles y que ingresaría de forma clandestina a través de la adaptación cinematográfica de Stanley Kubrick.

Ese lector, que se introduce de manera clandestina y que pasa a "estar en escena", como sucedía en la tragedia griega, no realiza una tarea de desciframiento sino que sobrecodifica, produce, amontona lenguajes (Barthes) que van dando cuenta de los rastros que deja una experiencia de lectura. ¿Pero como captar esos rastros? No es casual que Barthes recurriera a una metáfora cinematográfica para poder ejemplificar la forma en que se desarrolla una experiencia de lectura.

¿no os ha pasado nunca eso de leer levantando la cabeza? [...] Para escribir esa lectura, para que mi lectura se convierta, a su vez, en objeto de una nueva lectura, me ha sido necesario, evidentemente sistematizar todo esos momentos en que uno "levanta la cabeza” [...] Tomando como referencia las primeras proezas de la cámara, capaz de descomponer el trote de un caballo, en cierta manera, lo que he intentado es filmar la lectura de Sarrasine en cámara lenta. (35-36)

Ahora bien, Barthes se halla preocupado por precisar el lugar que la crítica literaria debiera ocupar de una vez por todas en tanto práctica de lectura, apartándose de esa larga tradición idealista que hacía del autor-creador el amo y soberano absoluto del sentido único de su obra, generándose con ello toda una moral crítica del justo sentido que expulsaba al lector fuera de la obra, y junto con él los riesgos de una contra-dicción profanadora. Aún hoy persisten, de alguna u otra forma, resabios de esa tradición, que se patentizan a la hora de apreciar un film basado en una obra literaria. Se continúa hablando, 
por ejemplo, en términos de una mayor o menor fidelidad con respecto al original literario; se dice del director que "ha respetado el sentido de la obra", o de lo contrario, que se aparta del mismo (dando con esto por sentado que el sentido de la obra literaria en cuestión es único); aún más, suele decirse también que se aproxima, se ajusta, penetra y extrae el espíritu de la obra. Por más inocentes que parezcan todas estas nociones, las mismas encierran, de forma más o menos explícita o implícita, una actitud de fetichización del arte que anula la dimensión política de su intervención en el desarrollo mismo de la historia. Es así como, ante el fenómeno de la adaptación cinematográfica, la pregunta a formularse debiera ser no cómo se filma una novela, sino cómo filmar una lectura, y con ello, los momentos de una intervención crítica-hermenéutica puesta a funcionar como política de interpretación. Ése es el punto clave desde el cual debiera partir siempre toda reflexión sobre la adaptación cinematográfica de un texto literario. Y visto de esta manera, ¿qué es entonces lo que cae (traspié) en el traspaso de una obra literaria a un film?: el mito de un sentido original, puro, único e irrepetible, y dado de una vez y para siempre por su autorcreador. Cae, en definitiva, lo que Benjamin señalaría como el fundamento cultual de la obra de arte, su aura. ${ }^{6} \mathrm{Y}$ es que iba a ser precisamente el cine — junto a la fotografía — lo que le permitiera a Benjamin encontrar la posibilidad de poder dotar al arte de una nueva teoría crítica que diera cuenta de sus condiciones de producción y reproducción, pensando el fenómeno artístico como inseparable del desarrollo tecnológico y por lo tanto de los nuevos modos de percepción que el mismo impone. Benjamin reflexiona en momentos en que una verdadera revolución tecno-perceptiva se está desarrollando, y encuentra la posibilidad histórica de una intervención política revolucionaria en el campo del arte que pueda despojar a éste de su fundamentación teológica y de su fetichización secularizada:

... por primera vez en la historia universal, la reproductibilidad técnica emancipa a la obra artística de su existencia parasitaria en un ritual. [...] en el mismo instante en que la norma de la autenticidad fracasa en la producción artística, se trastorna la función íntegra del arte. En lugar de su fundamentación en un ritual aparece su fundamentación en una praxis distinta, a saber en la política. (27-28)

Sin embargo nociones tales como creación, genialidad, autenticidad, original, perennidad, y misterio, entre tantas otras, parecen seguir insistiendo —-más que desde una teoría, desde una teología del arte - en el valor cultural de la obra artística. No es casual por lo tanto que las primeras aproximaciones del cine al mundo consagrado de la literatura fueran para dotar al primero de un status artístico del que supuestamente carecía por ser tan sólo una mera “disipación para iletrados”, como sostenían sus detractores; es decir, un simple pasatiempo para parias incultos. Dice Benjamin:

Resulta muy instructivo ver cómo, obligados por su empeño en ensamblar el cine en el arte, esos teóricos ponen en su interpretación, y por cierto sin reparos de ningún tipo, elementos culturales.[...] Es significativo que autores especialmente reaccionarios busquen

${ }^{6}$ La noción de aura se vincula con la adjudicación de un origen, con la idea de un "aquí y ahora” irrepetibles que constituyen la unicidad de la obra de arte y su ensamblamiento en el contexto de la tradición a través del culto. 
hoy la importancia del cine en la misma dirección, si no en lo sacral, sí desde luego en lo sobrenatural. (“La obra de arte en la época ...” 33)

Conviene por lo tanto no desentenderse de este origen sacralizador de la adaptación cinematográfica, que buscará en la literatura una forma de redimir al cine de sus pecados plebeyos. Dicho origen puede rastrearse en Francia a comienzos del siglo xx luego de que una crisis en el crecimiento sostenido de la industria ${ }^{7}$ planteara la necesidad de renovar los argumentos ante un público al cual ya no se lo iba a poder retener durante mucho tiempo más a base de una simple curiosidad óptica. Los productores comenzaron a plantearse entonces cómo “elevar” el nivel artístico del cine y recurrieron sin dudar a la literatura. En 1908 dos banqueros franceses, los hermanos Lafitte, fundan la productora Film d'Art e incorporan una serie de escritores ilustres ${ }^{8}$ que tendrán a su cargo — junto a las grandes actores de la Comèdie Française — la noble misión de enaltecer los argumentos y de llevar a la pantalla a Shakespeare, Dickens, Zola, Molière, Goethe y tantos otros genios de la literatura universal para que el cine se convierta en arte. Dice Gubern:

Todo el mundo rivaliza en la tarea de dignificar el cine con sus versos alejandrinos, barbas postizas, túnicas y gesticulación desbordada. ¿Será posible? Apenas el cine ha aprendido a narrar, a balbucear una historia sencilla y ya se pretende de él que exponga los conflictos de la tragedia griega [...] Los incultos norteamericanos, que no saben quién es Homero y que les importa un bledo la Academia Francesa, están haciendo progresar mientras tanto el cine con pasos de gigante, descubriendo los nuevos temas del Far-west [...] En América el cine está forjando su nuevo lenguaje con el empleo de las acciones paralelas, el uso del primer plano y la utilización de escenarios naturales. (61)

Cabe decir, finalmente, que del lenguaje mismo del cine surge un concepto, el de versión cinematográfica, que resulta quizás más apropiado para entender el fenómeno de la transposición más allá de una mera traducción de lenguajes. La versión es el modo que cada cual tiene de referir (narrar) un mismo hecho según la impresión que se tenga del mismo. Y si hablar de impresión es hablar necesariamente de imagen, esto nos reenvía a lo que veníamos planteando desde el comienzo. En primer lugar, que toda imagen es producida, luego, que quien dice imagen dice ilusión, puesto que el efecto de toda imagen es ilusorio - hecho que llevó a Jacques Lacan a sostener que todo sujeto en parte alucina su mundo. Además, vale decir que en una impresión lo que queda o se retiene no es el hecho en sí, sino su marca —alternación promovida en un cuerpo por otro extraño. Alteración producida, buena denominación para definir lo que la obra de arte es, y de paso insinuar el tipo de relación que establece con lo que le es extraño: lo real. El arte es la ilusión de un altercado con lo real. ${ }^{9}$

\footnotetext{
${ }^{7}$ Hacia 1907 Francia poseía el mayor volumen de producción de películas, mientras que los EE.UU. poseía el más vasto mercado de exhibición del mundo. (Véase Gubern 1997).

${ }^{8}$ Los Lafitte contrataron, entre otros, a Anatole France, Victorien Sardou, Edmon Rostand, y hasta Sarah Bernhardt, "a pesar de que la divina Sarah despreciaba el cine [...] pero se rendía, como cualquier mortal, ante los 1800 francos por sesión más un canon por metro de película” (Gubern 60). ${ }^{9}$ Conviene resaltar la riqueza operativa del término alteración desde la cual estamos proponiendo leer lo que es propio a toda representación, y en particular a la representación artística -la acción
} 
III. Tránsitos. Hacia una POlítica de LAS MEdiaciones

\section{III.1. El Cine / La Nación / El Policial}

Son muchas las obras de la literatura argentina llevadas al cine. Los buenos policiales, incluso, casi todos han merecido sus versiones fílmicas. Nuestra perspectiva de lectura se sostiene desde una construcción metodológica que debe pensarse en función de una doble articulación. La primera, aquélla que responde al género: el policial. La segunda, aquélla que da cuenta de la elección discursiva que estos films realizan frente a las obras que transponen en un contexto de discusión estético-político específico.

Si como dice David Viñas, la literatura argentina emerge alrededor de una metáfora mayor, la de la violación (15), y toma como obras-comentarios de esa violencia exterior que va “de la 'carne' sobre el 'espíritu'” a El matadero de Esteban Echeverría y a Amalia de José Mármol, no resulta, entonces, muy arriesgado afirmar que la expansión de esa metáfora de la violencia es también fundacional en el cine. ${ }^{10}$ En principio, así como Viñas coloca la narración como instancia fundadora de la literatura nacional, en el cine, esa instancia fundadora debe buscarse en la transposición de las imágenes que cada literatura nacional fue capaz de construir en el imaginario colectivo de esa Nación. En otras palabras, la narración, como dice Benedict Anderson, está en la base de los relatos cohesionantes de la Nación moderna y capitalista, y nosotros agregamos que sin esos imaginarios nacionales el cine nunca hubiera tenido el impacto popular que tuvo. Y aquí volvemos a lo que decía Panofsky acertadamente. Primero fueron esos frames proyectados en bares y tabernas, pero la verdadera dimensión popular aparece cuando las imágenes pasaron a narrar y una especie de nueva épica emergió de esos pictures que pasaron a ser movies.

En Argentina, recordemos, la Generación de 1880 había hecho todo lo necesario para que el país ingresara al capitalismo. ${ }^{11}$ Su estructura de producción agroexportadora estaba en plena expansión y a comienzos del siglo xx casi totalmente integrada y dependiente de las políticas capitalistas de los países centrales e industrializados. En este esquema económico, hacia 1890 una incipiente autonomización del campo cultural nos permite

de alterar algo y alterarse remite a la noción indispensable del otro (alter), o de lo otro, que está en la constitución misma de toda identidad. Pero además, alterar es perturbar, irritar; producir un sobresalto; generar una disputa, un altercado, una contienda ... una revuelta. ¿Acaso no fueron estas las banderas de toda vanguardia, que vinieron a poner en crisis la idea misma de representación? ${ }^{10}$ "Cinema is a popular cultural institution that helps to mediate a broad spectrum of social meanings, values, and structures" (Tudor, 1972). "Yet depictions of violent behavior are special. They invoke some of society's most central and guiding values, those which justify the use of force, illuminate the parameters of social order, and demarcate legitimate from illegitimate action. Put simply, the place of violence in social life lends special significance to public discourse about violence in films. The history of film violence thus offers one account of cinema's evolving role as a crucible of standards of legitimate action and social order" (Slocum 651).

${ }^{11} \mathrm{La}$ bibliografía para este punto es profusa, pero muy pocos autores plantean con la claridad que lo hace Oscar Oszlak, la densidad de elementos materiales e ideológicos a tener en cuenta a la hora de estudiar el desarrollo del capitalismo de Estado en Argentina. 
visualizar algunos focos independientes de producción cultural. Esos focos llegarán al Centenario funcionando acertadamente. En consonancia con el esquema capitalista, una industria cultural elemental comenzaba su afianzamiento.

Cuando el cine da sus primeros pasos, cautiva de inmediato al público argentino y muchos medios de esa industria cultural comenzarán rápidamente a dar cuenta de aquél fenómeno. El caso más significativo quizás — pero no único — es el de Horacio Quiroga. Este autor se ganaba la vida escribiendo relatos, cuentos y ensayos para revistas y periódicos populares. Tempranamente, demostró una sensibilidad especial para el cine, no sólo para comentar las películas que veía sino también para todo aquello que rodeaba a esta nueva expresión artística. Su compenetración con el cine fue tal que no sólo lo llevó a escribir cuentos memorables como "Miss Dorothy Phillilps, mi esposa", sino que hasta lo impulsó a escribir dos guiones: uno, recreando su cuento "La gallina degollada”, y otro, “más guión”, La jangada. Si bien ninguno de los dos llegó a filmarse nunca, ambos guiones nos permiten hoy visualizar los elementos centrales de la concepción ideológica y estética del cine de Horacio Quiroga, pero también, - - y esto es tan importante como lo anterior - a entender cómo el autor metaboliza el cine en su literatura. ${ }^{12}$

Con el devenir del cine sonoro y hasta la aparición del doblaje y el subtitulado, Hollywood encuentra dificultades para llegar a todos los públicos y retrocede significativamente en el mercado latinoamericano. En América Latina, donde el inglés es un patrimonio de los sectores más cultos de las elites gobernantes, se impone rápidamente una política de "sustitución de importación” de películas y las compañías que antes importaban los films, se lanzan a financiar emprendimientos locales. Claro que este desarrollo sería asimétrico para los diferentes países de la región y apenas factible para aquellos en donde ya existía un público. Argentina y México serían junto a Brasil, los países con más rápida adaptación a esta nacionalización del cine. Los dos primeros, incluso, se convertirán hasta bien entrados los años cuarenta en la gran meca del cine y la industria cinematográfica de América Latina. ${ }^{13}$

${ }^{12}$ Recordemos que Horacio Quiroga viajó de muy joven como fotógrafo de la expedición a las ruinas jesuíticas en el litoral argentino encabezada por Leopoldo Lugones. Este hecho nos habla de su temprano interés por las imágenes y el arte de la fotografía. Más tarde, entre 1918 y 1931, escribirá sesenta y ocho comentarios y notas sobre el cine. Comienza en la revista El Hogar en 1818. En 1919 se pasa a la revista Caras y Caretas, a donde enviará sus notas sobre cine hasta 1920. Tras dos años de retiro en la selva misionera, donde trata de ponerle orden a su vida privada, entre el 4 de mayo y el 21 de diciembre de 1922 vuelve a comentar cine para la revista Atlántida. Otro largo período de silencio en la Selva que lo aleja del cinematógrafo. Entre 1927 y 1928 vuelve a escribir algunos excelentes artículos para El Hogar, pero el cine ya parece importarle poco. Menos aún el sonoro. Sus últimos artículos sobre el tema se publican en La Nación, en 1929 (donde manifiesta su visión del cine sonoro, en "Espectros que hablan") y en 02/08/1931, "Escuela normal de cinematógrafos," donde se burla de la posibilidad de escolarizar la enseñanza del cine. Su proyecto de guión cinematográfico La jangada es de 1917 y fue el intento de conformar con Manuel Gálvez una empresa cinematográfica. La jangada es la adaptación de dos cuentos suyos, "La bofetada” (1916) y “Los Mensú” (1917) y como bien lo ha señalado Carlos Dámaso Martínez, éste es un intento muy rudimentario por escribir un guión y se nota de qué modo su fascinación por el cine de Hollywood lo lleva a "universalizar" su aldea.

${ }^{13}$ Este período, que va de los primeros años de la década del treinta a mediados de los años cuarenta, es el que se conoce como la "época de oro" del cine nacional argentino. De él surgió todo un star 
Sin embargo, esta nacionalización del cine no sólo puede reducirse a los efectos colaterales de la sonorización, sino que también está vinculada al proceso de emergencia de los movimientos nacionalistas y populistas ${ }^{14}$ que recorrerán a estos países centrales de América Latina desde los tempranos años treinta. Lázaro Cárdenas en México y su expropiación del petróleo a las compañías extranjeras en 1938, Juan Domingo Perón en Argentina y su nacionalización, en 1949, de los ferrocarriles ingleses, o bien Getulio Vargas en Brasil y la creación de PetroBras en 1951. También podríamos pensar, en este sentido, en movimientos como el de José María Velasco Ibarra (1952-1956) en Ecuador, o bien el de Víctor Raúl Haya de la Torre y su APRA en Perú, cuyo programa ejerció una importante influencia en su país en los años cincuenta, o bien Víctor Paz Estenssoro en Bolivia, que en 1952 decretó la nacionalización de las minas y la reforma agraria.

Ahora bien, así como la novela fue la encargada de narrar el surgimiento de una nueva clase social, la burguesía, y la emergencia de un nuevo orden económico mundial, basado en el sistema de producción capitalista, no es menos cierto que en su seno tendrá lugar una temprana confrontación ideológica por la hegemonía de los géneros discursivos. En esta disputa, el policial ha sido caracterizado como la estilización cabal en donde emergen los tópicos de la racionalidad moderna (esto es, capitalista) de Occidente. El policial es el temprano lugar en donde la razón se impone como principio de igualdad. Es en el policial donde los lectores pueden leer los signos realistas de la sociedad en que viven, donde la violencia y el delito se imponen como realidad (y a veces como caminos válidos para la movilidad social ascendente). ¿ Pero la literatura policial es funcional al sistema capitalista, es decir, asume un papel moralizante, o es un dispositivo capaz de poner en crisis a los sujetos de la modernidad? La respuesta asume su relevancia en sus transformaciones internas, cuando señala el camino que va del relato de intrigas y acertijos al relato policial negro. Una transformación que en nuestro país pondrá en discusión a dos grandes intelectuales: Jorge Luis Borges y Roger Caillois. ${ }^{15}$

Este debate tiene en su base una disputa sobre el origen del género, (anglosajón para Borges y/o francés para Caillois), y tiene también su importancia para las letras argentinas, porque de alguna manera escenifica las tradiciones que se irán definiendo en torno al

system de comedias de “Teléfonos blancos”, (entre los que encontramos a las hermanas Legrand, Zully Moreno, Libertad Lamarque, Eva Perón, Analía Gadé, Lolita Torres, Tita Merello, Luis Sandrini, Pedro Cuartuchi, entre tantos otros) que no sólo alcanzó la fama dentro de las fronteras argentinas, sino que sus nombres se hicieron populares en toda América Latina. Para el desarrollo del caso mexicano, recomendamos ver Aurelio de los Reyes, Medio siglo de cine mexicano. 18961947.

${ }^{14}$ Mucho se ha escrito sobre el populismo en América latina, pero en palabras de Alain Touraine, el concepto encuentra una interesante precisión. "El populismo siempre ha sido la gran tentación latinoamericana, representando un deseo de cambio con continuidad, sin la ruptura violenta que experimentaron tanto los procesos socialistas como capitalistas de industrialización.” (citado por Castañeda 45).

${ }^{15}$ Para un desarrollo completo del debate, véase Analía Capdevilla, “Una polémica olvidada. (Borges contra Caillois sobre el policial)” 65-78. Para los interesados en profundizar sobre la figura de Roger Caillois, sobre su presencia en Buenos Aires, su participación en Sur y su amistad con Victoria Ocampo, recomendamos el número monográfico de Europe. Revue littéraire mensuelle, (París) Année 78, n859-860, Novembre-Décembre 2000. 
policial argentino. El debate tuvo su punto de inicio en la reseña que Jorge Luis Borges hiciera sobre el libro de Roger Caillois, Le roman policier, en el número 91, abril de 1942 de la revista Sur, la revista fundada y dirigida por Victoria Ocampo (Felgine 90). El debate continúa y termina en el número 92. ¿Qué líneas quedan asentadas allí sobre la fundación del género y de qué modo ellas tienen importancia para las tradiciones del policial argentino? Para Borges, ${ }^{16}$ el género nace en 1841 cuando Edgar A. Poe publica Los crímenes de la calle Morgue. Para Caillois, en cambio, el nacimiento se deriva del impacto social (de temor, amenaza y desconfianza) que genera en la población del Primer Imperio con Napoleón la aparición de la policía secreta y reconoce como “precursor” a Honoré de Balzac y su Une ténébreuse affaire. El debate tiene otros puntos, pero como bien señala Analía Capdevila, tanto Borges como Caillois comparten la concepción de que el policial renueva las estructuras literarias y abre las posibilidades de un cambio sustancial en la literatura que vendrá.

Años después, terminada la Segunda Guerra Mundial, un proceso de asimetría distancia a Europa de América Latina respecto al debate cultural en curso. En Francia en especial, pero en varios países de Europa, en general, el horror de la guerra parece poner en crisis el canon realista de la literatura y su concepción de la representación literaria. La literatura ya no parece poder dar cuenta del horror en términos de representación. La larga trayectoria realista-naturalista de la literatura francesa es “jaqueada” y cuestionada. El camino hacia el absurdo; la literatura experimental y el nouveau roman atestiguan este ataque al paradigma realista-naturalista. Alientan, entre otras cosas, la expansión del existencialismo sartreano y el debate político contra el dogma del realismo socialista.

Contrariamente a Europa, las fuerzas políticas adscriptas a los nacionalismos populistas en América Latina logran, desde el poder del Estado, legitimar en el centro de la industria cultural de masas a aquellas expresiones culturales y estéticas de las clases subalternas. En Argentina, ese proceso se hace sobre la tradición de la literatura realista de Boedo y el rescate de los particularismos provinciales. El debate, por lo tanto, se remonta a los tiempos de las escuelas de vanguardia clásicas. Esta asimetría se ve alimentada y profundizada por el particular proceso que se da a fines de los años cincuenta en América Latina con la Revolución Cubana. El latinoamericanismo parece conquistar un lugar y, en ese camino, los intelectuales de las elites nacionales parecen encontrar en el modelo cubano una salida "por izquierda" a los nacionalismos populistas. Es tan fuerte la institucionalización de la política cultural cubana como modelo alternativo que sin el debate que éste impulsa, quizás el boom de la literatura latinoamericana no hubiera tenido lugar. ${ }^{17}$

En Argentina, una particularidad más nos ayuda a comprender este fenómeno. El peronismo clásico (1946-1955), como todo movimiento nacionalista populista, propuso

\footnotetext{
${ }^{16}$ Jorge Luis Borges ya había publicado en Sur, Año 5, nº 10 , julio de 1935, su preceptiva del cuento policial, ”Los laberintos policiales y Chesterton”. El lector podrá consultar éste y los textos de la polémica con Caillois, en la compilación de Sara Luisa del Carril y Mercedes Rubio de Socchi. ${ }^{17}$ El ejemplo más claro es Casa de Las Américas, y toda su política de premios, encuentros y congresos de escritores que propicia, como así también la importante generación de artistas, cineastas e intelectuales que ven en Cuba un lugar desde donde desarrollar un arte comprometido, un lugar desde donde ejercer el engagement sartreano.
} 
un dispositivo de control cultural muy férreo sobre los discursos disidentes, y para ello supo utilizar contundentemente los medios masivos de comunicación y el aparato estatal de educación. Liberales y marxistas eran desde los tiempos de "Braden o Perón" igualmente enemigos del gobierno popular. ${ }^{18}$ Por eso, con la caída del peronismo en 1955, marxismo y liberalismo volvieron a sus naturales diferencias y el debate se encauzó hacia los viejos tópicos de la cultura letrada (vs) la cultura obrera. ${ }^{19}$ Por otro lado, el pensamiento marxista se expandió de los libros (a los que tenían acceso apenas algunos pocos intelectuales) a las revistas (patrimonio fundamental de las clases subalternas en las sociedades de masas); y en esta expansión, las culturas de izquierda se vieron impulsadas a una popularización de sus ideas. Irrumpe al calor de este proceso toda una generación de intelectuales que logran poner de manifiesto la irracionalidad que el debate entre peronistas y antiperonistas adquiere en la cultura argentina. Ellos impulsan una renovación crítica, donde el campo cultural logre su autonomía de las viejas instituciones de la política criolla (oligárquica-liberal) y/o de las recientes expresiones peronista-populista. La vía de esta renovación comienza con Sartre y el existencialismo, sigue con Freud y el psicoanálisis y con Marx y el marxismo. La irrupción de esta nueva generación está en la base de esta irrupción de la crítica. ${ }^{20}$

Mientras este debate asimétrico entre Europa y América Latina tiene lugar en el seno de la literatura, donde incluso algunas voces como las de Julio Cortázar suenan tan disonantes a los oídos de los defensores más ortodoxos del realismo socialista, ${ }^{21}$ en el cine parece acontecer otra asimetría, en este caso, con la literatura. En el cine, el neorrealismo italiano, que ha mostrado la posibilidad de un cine con identidad propia, alternativo a Hollywood, de calidad y de alta performance industrial, contagia de un vitalismo inusitado

\footnotetext{
${ }^{18}$ Recordemos que el general Perón llegó a su primera presidencia confrontando con la Fórmula Tamborín-Mosca (apoyada tanto por los liberales de la embajada de EE.UU. como por los miembros del Partido Comunista Argentino que, siguiendo los lineamientos del PCUS y su política de los "Frentes antifascistas", caracterizaba a Perón como un fascista y al peronismo como un movimiento de masas proto-fascio). El lema de campaña del peronismo en aquellos años fue "Braden o Perón". Braden, era el embajador de EE.UU. en Argentina.

${ }^{19}$ Véase el debate Borges - Sábato que compiláramos para Cuadernos Hispanoamericanos. Lo que se pone de manifiesto allí son las visiones de dos intelectuales de raíces disímiles, que tras haberse opuesto al peronismo en su época de hegemonía, discuten entre ellos tras la caída de Perón del poder en 1955. Borges no tiene concesiones y caracteriza a Perón como a un "tirano prófugo". A Sábato, su pasado comunista lo lleva a intentar despegarse del esteticismo borgeano y el de su amigo “Adolfito" (por Bioy Casares), cabales representantes de la literatura de evasión, del arte por el arte. ${ }^{20} \mathrm{Para}$ este punto, véase los artículos Horacio Crespo, María Sondereguer y Horacio Tarcus, en la § Pensamiento, en Historia crítica de la literatura argentina 423-99.

${ }^{21}$ Julio Cortázar tuvo cuatro polémicas en su carrera literaria. La primera con José Ma. Arguedas, entre 1968-1969; la segunda con Oscar Collazos (1969-1970); la tercera con David Viñas entre (1971 y 1972), y la cuarta con Liliana Heker. En todas estas polémicas, la relación literatura/política estuvo en el centro de la discusión. Cortázar defendía la independencia de la literatura de la política y reclamaba que la verdadera revolución en literatura era la ficción. Sin embargo, Cortázar cayó en la tentación realista y escribió El libro de Manuel (1973) por el que fue profundamente criticado. Nunca más se lo perdonaría a sí mismo y no dejaría de defender la ficción fantástica como el gran género de la literatura subversiva. Muchos de los marxistas latinoamericanos no se lo perdonarían.
} 
a las filmografías nacionales de este lado del océano Atlántico. El cine de Hollywood no escapa a estas pretensiones y hace realismo dentro de sus posibilidades con el cine bélico y el western. Es que el realismo se vuelve el arma ideológica de esas narraciones de construcción de identidad nacional. El cine está obligado a ser realista para ser nacional. Necesita representar a su gente, a su lengua, a su historia. Los relatos literarios devienen en el inconsciente de la patria. Por eso el cine y el psicoanálisis comparten algo más que una época; ambos se interrogan sobre algo que saben pero que no está allí, en la conciencia o razón tal como la pensaba Descartes. Ambos ven en esas imágenes un conjunto de fuerzas o pulsiones que deben ser encauzadas. Ambos, el cine y el psicoanálisis, creen tener un proyecto emancipador teleológico acorde a los nuevos tiempos y a la nueva sociedad industrial burguesa. En este sentido, podemos afirmar que sin cine realista, no hay filmografía nacional. Pero ya no hablamos de la nación de la Ilustración, hablamos de la nación capitalista de posguerra: el cine bélico (en EE.UU.), el cine de intriga y espionaje (en Inglaterra), ${ }^{22}$ el cine psicológico noir (en la Francia republicana), etc., etc.

El cine argentino no escapará a estas líneas de fuerza del realismo. Su principal representante será Leopoldo Torre Nilsson, quien a lo largo de su intensa carrera en el cine, llevó, como ningún otro director argentino, una extensa lista de obras literarias al cine. Podríamos comenzar con El crimen de Oribe (1950) $)^{23}$ sobre la novela de Adolfo Bioy Casares El perjurio de la nieve, seguido por Borges y sus Días de odio (1954) ${ }^{24}$ adaptación del cuento "Emma Zunz", o bien Graciela (1956) ${ }^{25}$ sobre la novela Nada de Carmen Laforet o bien Los siete locos (1973), ${ }^{26}$ adaptación de las novelas de Roberto Arlt Los siete locos y Los lanzallamas, o bien Boquitas pintadas $(1974)^{27}$ sobre la novela homónima de

${ }^{22}$ Para comprender por qué Hitchcock y no otro autor es el mejor representante de ese nacionalismo cinematográfico inglés, y de qué modo su filmografía hunde sus raíces en la tradición de esos relatos fundantes a los que nos referíamos más arriba, nos remitimos a lo que nos señala Lilían Duarte en su trabajo “A (des)ordem internacional pelas lentes de Alfred Hitchcock”. Allí escribe nuestra autora: "Hitchcock alegava sentir escasso interesse por enredos em que os personagens se reúnem, generalmente comandados por un Poirot, para descobrir o culpado de um crime. Para o diretor, a trama deveri desenvolver-se impulsionada por lances inesperados ao longo de todo filme. uma vez conquistado o interesse do espectadorr, este seria ao, mesmo tempo, cúmplice da ação e surpreendido por ela a cada momento. Esse ambiente que envolve os personagens -de incerteza, de ansiedade, de violencia que brota nos momentos de aparente tranqüilidade-é um dos pomtos mais fortes de convergencia entre Alfred Hitchcock e Thomas Hobbes. A vida é cruel, vil e curta, concordam os dois ingleses, porque o homem é o lobo do homem, os seres humanos vivem em permanente estado de competição, sempre dispostos a aniquilar os semelhantes. o medo da morte permeia toda a existência” (154-55).

${ }^{23}$ En codirección con su padre. 87 min. Intérpretes: Roberto Escalada, Carlos Thompson, Ma. Concepción César, Diana Wells y Delia Crisitiani entre otros.

${ }^{24} 70$ min. G.. Leopoldo Torre Nilsson y Jorge Luis Borges. Int. Elisa Christian Galvé, Raúl del Valle, Duilio Marzio y Nicolás Fregués.

${ }^{25} 80$ min. Int. Elsa Daniel, Lautaro Murúa, Susana Campos, Amalia Britos, Mónica Linares, Beto Gianola, entre otros.

${ }^{26} 118$ min. Int. Alfredo Alcón, Norma Aleandro, Thelma Biral, Héctor Alterio, Sergio Renán , Osvaldo Terranova, Leonor Manso, entre otros grandes actores.

${ }^{27} 120$ min. Int. Alfredo Alcón, Luisina Brando, Marta González, Raúl Lavié, Leonor Manso, Cipe Lincovski y Mecha Ortiz, entre otros. 
Manuel Puig. Todo esto sin contar las novelas de su mujer, la narradora, Beatriz Guido, y el cine épico, entre los que contamos Martín Fierro (1968), ${ }^{28}$ El santo de la espada $(1970)^{29}$ y Güemes, la tierra en armas (1971). ${ }^{30}$

\section{III.2. De la literatura al cine}

\section{III.2.1. Emma Zunz - Días De Odio}

Ricardo Piglia dijo alguna vez que “Emma Zunz” era el primer cuento obrerosocialista de la literatura argentina ya que pone en escena, como ninguno, la lucha de clases. La observación es interesante, sin embargo Piglia va más allá y ubica la historia en la tradición del relato policial negro. En el cuento, el acertijo requiere dos o tres frases para explicar la venganza de Emma a la memoria de su padre. Una “justicia finita” se desata con la carta que le anuncia a Emma, aquella tarde después del trabajo en la fábrica, el suicidio de su padre en Brasil. Es un "relato blanco", dirá Piglia, que se caracteriza por "El estilo elusivo y antisentimental de Hammett y de Hemingway, que marca un momento de viraje en la historia del género...” (13). Por eso, el acertijo se vuelve muy difícil de narrar con imágenes. El relato es de apenas cinco carillas. El giro del género lo inscribe en la tradición angloamericana. Emma burla la justicia del Estado con su justicia personal, y restituye así todas las moralidades quebradas por Aarón Loewenthal: la estafa, que inculpa al padre de Emma y le permite adueñarse de la fábrica; su lascivia, que le permite explotar a sus obreras y abusar sexualmente de ellas; su codicia desmedida, que lo lleva a trabajar — aun cuando es judío- el sábado (Emma lleva a cabo el asesinato el día sábado). Torre Nilsson está, sin duda, más preocupado en el lenguaje cinematográfico neorrealista que en la trama ficcional. Lucha por extender el relato para convertirlo en un largometraje. Su preocupación por los exteriores es notable. Hay efectos de sonidos muy audaces (la ropa tendida en una soga flameando por el viento en un patio de los suburbios) para la época, que tienden a atemperar esos largos silencios literarios. El odio se representa en esos sonidos y Torre Nilsson lo sabe.

Pero novela y film son dos cosas distintas. El film es muy interesante y tiene una estructura narrativa increíble para el cine de aquellos años. Borges, a pesar de haber participado en la escritura del guión con Torre Nilsson, se sentirá defraudado por los resultados.

${ }^{28}$ El guión de este film fue escrito entre Leopoldo T. Nilsson, su mujer, Beatriz Guido y Ulyses Petit de Murat y Edmundo Eichelbaum. 134 min. Int. Alfredo Alcón, Lautaro Murúa, Fernando Begal, Graciela Borges, María Aurelia Bisutti, Leonardo Favio, Sergio Renán, Juan Carlos Lamas.

${ }^{29}$ Sobre la novela homónima de Ricardo Rojas que narra la vida de San Martín. 120 min. Int. Alfredo Alcón, Evangelina Salazar, Lautaro Murúa. Ana María Picchio, Héctor Alterio, Juan Carlos Lamas, Eduardo Pavlovsky, Leonor Benedetto, Eduardo Nóbili, Carlos Luccini y Hugo Arana.

${ }^{30}$ Para el guión de esta película, Leopoldo T. Nilson recurre otra vez a la experiencia de Martín Fierro y convoca a Ulyses Petit de Murat, y a Beatriz Guido. 100 min. Int. Alfredo Alcón, Norma Aleandro, Gabriela Gilli, Luis Mathé y Mercedes Sosa, entre tantos otros. 
Agregó una historia sentimental que no tenía por qué figurar, y lo llenó de toda suerte de detalles sentimentales que parecen contradecir la historia, que es una historia dura. Yo lo aconsejé a él que no podía hacerse un film con "Emma Zunz”. (Sorrentino)

En contraposición, Torre Nilsson nunca dirá que su film fracasa. Para él, ha dado en la clave. Quizá, una clave muy cercana a la de Piglia y distante a la de Borges.

"Emma Zunz”, era la historia de una soledad, en contraposición con un medio. Era una historia mucho más vieja, pero quizá más rica y expresiva. Era de alguna manera, la historia de todas las soledades, de todos los odios, de todas las venganzas. Esto es quizá, lo que más allá de todas las peripecias psicológico-argumentales de Días de odio he tratado de mostrar el repetido contrapunto del hombre y la sociedad. (Couselo, Historia 144)

Josefina Ludmer traza otra genealogía - la que lleva a Torre Nilsson con su cine a unir a Borges y Arlt con el peronismo. Es que la película de Nilsson apela a un tiempo actual y esa actualidad es aún en tiempos del peronismo. En los exteriores, Nilsson deja que ese tiempo exterior entre en el film. Ya no son los graffitis anarquistas de los años veinte (tiempo del relato borgeano) los que incitan a la lucha en los barriales fabriles, sino que ahora están por detrás las consignas de Eva Perón y los descamisados. Ese tiempo actual resignifica y traspone el film en otra dirección. Por eso Torre Nilsson dirá después:

Debo decir que mi proyecto más audaz, que fue Días de odio, fue prohibido para la exportación, y virtualmente sus posibilidades de distribución en el país se limitaron al máximo, no sé si porque era la obra de un autor no visto con simpatía por el gobierno, o porque se pensó que el tema era demasiado negro o desagradable, que no mostraba una Argentina demasiado feliz en alguno de sus personajes. (1961, Radio Universidad de Córdoba en diálogo con Tomás Eloy Martínez. Citado en Couselo, Historia 145)

Solo ochenta mil personas vieron Días de odio. Con Días de Odio vuelvo a ser minoritario. Se prohibió que la película fuera vendida en el exterior y se limitó al máximo su distribución en el país. (Ludmer 420)

Para cerrar la visión de Torre Nilsson, nos resta citar lo que el autor pensaba por aquellos años, muy cercanos a Días de odio y que puede considerarse el nudo de su poética cinematográfica, ya que nunca se corrió de esta postura, e incluso, podríamos decir, la fue profundizando con el paso de los años.

El cine no es una golosina para empalagar imbéciles ni un sedante para calmar dolores de cabeza. El cine debe ser un dedo acusador, un descubridor de una llaga, un vociferador de la verdad. (diario El Mundo, 24/09/1958, citado en Couselo, Historia 154)

\section{III.2.2. Toribio Torres, Alias Gardelito - Alias Gardelito}

Lautaro Murúa puede considerarse una extensión-evolución del cine de Torre Nilsson. Dirigió seis películas, de las cuales cuatro se basaron en novelas "literarias" de 
autores argentinos y pueden considerarse, todas ellas, verdaderas transposiciones cinematográficas. Esas cuatro películas fueron. Shunko (1960), ${ }^{31}$ sobre la novela de Jorge W. Ábalos; Alias Gardelito (1961) ${ }^{32}$ sobre una nouvelle de Bernardo Cordón; Un guapo del $900(1971)^{33}$ sobre la pieza teatral homónima de Samuel Eichelbaum y Cuarteles de invierno (1984) ${ }^{34}$ sobre la novela del mismo título de Osvaldo Soriano. Entre estas dos últimas películas, dirigió el film que más popular lo haría como director. La Raulito (1974) $)^{35}$ y su continuación, La Raulito en libertad (1977). ${ }^{36}$

Más allá de que su película La Raulito fuera la encargada de fijarlo frente al gran público como director de cine, su mejor película es, sin duda, su excelente transposición del relato de Bernardo Kordon. ¿Cuál fue su clave? La de realizar un cine de tesis, donde su postura frente a la realidad social nunca llegara al extremo de lo manifiestamente político. ¿Cómo se logra esto? Exigiendo siempre que sea la realidad la que entre en la lógica del discurso cinematográfico y no que el discurso cinematográfico ingrese en la lógica de la realidad. Con otras palabras, la distancia que hay entre realidad y film siempre es mediada por la ficción. Esta perspectiva dota al cine de Lautaro Murúa de un vitalismo capaz de llevar al espectador de las narices al nudo de la narración. Lautaro Murúa integra aquella denominada nueva generación del sesenta, pero su cine estaría a medio camino, in media res, entre aquel cine intelectual que practican Torre Nilsson, David José Kohon, Arturo Cerretani, Arturo Khun, o Manuel Antín, y aquel cine político que a partir de

\footnotetext{
3176 min. G.. Augusto Roa Bastos. Int. Lautaro Murúa, Raúl del Valle y Fanny Olivera. La crítica especializada no fue muy benévola con la actuación de su director. En la revista Tiempo de Cine se decía: "Entendemos que Shunko presenta ostensibles fisuras en su arquitectura dramática, muchos errores de dirección de intérpretes...” (Un diccionario de films argentinos).

${ }^{32} 80$ min. G.. Augusto Roa Bastos. Int. Alberto Argibay, Walter Vidarte, Lautaro Murúa, Virginia Lago, Nora Palmer y Raúl del Valle. Contrariamente a lo que se dijo en la película anterior, la crítica especializada recibió a esta película de manera estruendosa. También en Tiempo de Cine, se decía: "Demolición de mitos escapistas, Alias Gardelito es, en ese aspecto, un acto quirúrgico y necesario. Murúa utiliza un lenguaje directo y a la vez elíptico, concentrado en secuencias que se cierran en sí mismas pero sin progresiones dramáticas tradicionales...” (Un diccionario de films argentinos). ${ }^{33} 110$ min. G.. L.M. y Néstor Gaffet. Int. Lautaro Murúa, Jorge Salcedo, Chunchuna Villafañe, China Zorrilla y Raúl Lavié. Esta fue la apuesta fuerte y ambiciosa de Lautaro Murúa. Primero se remontaba a dos versiones anteriores, la primra de Lucas Demare, de 1952 (film que quedó inconcluso) y la segunda la de Leopoldo Torre Nilsson, que contaba como guionista al propio autor de la pieza teatral, Samuel Eichelbaum. La crítica volvió a ser despiadada con Murúa. "El come-back de Murúa a la dirección después de once años es una película fallida y anticuada, muy lejos de la versión de Torre Nilsson” (Un diccionario de films argentinos).

${ }^{34} 115$ min. Int. Oscar Ferrigno, Eduardo Pavlovsky, Ulises Dumont, Arturo Maly y Enrique Almada, entre otros.

${ }^{35}$ Esta historia había sido escrita para televisión, titulada Nadie por la escritora Martha Mercader y Juan Carlos Gené. Fue adaptada para Murúa por José Ma. Paolantonio. 95 min. Int. Marilina Ross, Duilio Marzio, María Vaner, Fernanda Mistral, Jorge Martínez y Virginia Lagos entre otros.

${ }^{36} 94$ min. Int. Marilina Ross, Vicente Parra, Lautaro Murúa, Erica Wallner y Charo López, entre otros. Se trata de una segunda parte hecha "por dinero" en España, en tiempos de la dictadura militar y a modo de aprovechar el éxito que la primera, La Raulito, había obtenido en España, en pleno posfranquismo. La película fue estrenada en nuestro país en 1985, al regreso de la democracia.
} 
Fernando Birri comenzarán a practicar un conjunto de jóvenes realizadores desde 1969 hasta 1976, entre ellos Pino Solanas, Octavio Getino y Gerardo Vallejo, (el grupo Cine Liberación) donde el cine es considerado un instrumento de lucha para la liberación y la revolución. ¿Qué características adquiere esta forma de hacer cine in media res? Básicamente, insistimos, en no perder el eje narrativo basado en la ficción. La cámara adopta —y éste es el mejor ejercicio que Lautaro Murúa realiza en Alias Gardelito — una postura testigo, pero sin llegar a la posición extrema del zoom documental, hallazgo de la escuela soviética de Eisenstein. ${ }^{37}$

Este recurso de Lautaro Murúa en cine ya parece estar en los mejores textos de Bernardo Kordon, entre ellos, la nouvelle que servirá de base de Alias Gardelito. ${ }^{38}$ Por eso Lautaro Murúa logra la contundencia que no consiguió en Shunko o que no conseguirá en posteriores trabajos como Un guapo del 900 o en Cuarteles de invierno. La narrativa

${ }^{37}$ Cabe señalar aquí que hacia 1970 las tendencias hacia la politización del cine son cada vez más fuertes, y si bien desde el grupo Cine Liberación se va hegemonizando una tendencia a la politización de "contenidos", desde otro lugar opuesto la vanguardia cinematográfica introduce una crisis interna en los planteos de cómo debieran ser las relaciones entre arte y política, desplazando la problemática al aspecto "formal" desde el cual poder radicalizar una posición política más acorde a la autonomía del arte que se defiende. Es así que La hora de los hornos, de Solanas, y The Players vs Ángeles Caídos, de Fischerman, marcan los extremos opuestos de esta confrontación. "En ese momento había dos caminos muy definidos. El camino de Solanas era un camino de documental totalmente falseado, fabricado, con estudiantes de actores (como se hacen los comerciales testimoniales aún hoy) que hacían de obreros y hablaban con un naturalismo que sólo es posible porque hay conocimientos de actuación. No es el neorrealismo italiano, sino que se actúa. Casi toda La hora de los hornos está filmada así, es un documental fingido con un sonido que se le agrega a la imagen, porque la imagen no tiene sonido propio porque está actuada. Es un documental tipo Octubre (Solanas es muy inteligente cinematográficamente), con todo muy orquestado [...] Fue una gran maniobra para atraer a una gran cantidad de estudiantes que en ese momento eran marxistas, que eran hijos de antiperonistas, que habían sufrido el peronismo en el colegio, toda una generación que no dependió de los regalos de Evita, a quienes los regalos de Evita no los habían tocado en el corazón para siempre. [...] La hora de los hornos fue un elemento utilísimo para convencer a toda esa gente de que la historia había sido diferente, que se estaba luchando contra la oligarquía, cosa que a lo mejor era cierta y que hace a la complicación del fenómeno peronista. De todos modos, todos los que estábamos ahí estábamos contra La hora de los hornos. Había varios tipos de razones. Por razones estéticas, políticas (aunque el tigre Cedrón era peronista), por razones personales porque había un acto de arribismo total. Una cosa era hacer las películas que después hizo el Tigre, que mal o bien le costaron la vida, y otra cosa era hacer este asunto de Solanas con Jorge Antonio, que era un gran comercial hecho con objetivos políticos. E incluso podía dejar dinero. Por eso no estábamos de acuerdo con esa línea. En realidad preferíamos hacer publicidad, vivir de otra cosa. Además, todas las películas que se hicieron esa noche (y las que estábamos filmando en ese momento) eran más de vanguardia que la de Solanas, que hecha en Rusia en 1920 podía ser valorable, pero en Buenos Aires en 1970 no era sino sorprender a los incautos con técnicas que yo creo que estaban muy superadas” (Julio Ludueña, grabación del 29 de agosto de 1995 citado por Sarlo 243-54, nota 25).

${ }^{38}$ Bernardo Kordon murió en Chile, absolutamente solo y olvidado, la primera semana de febrero del 2002. Apenas unos años atrás, huyendo de la pobreza en la que vivía en Buenos Aires, había declarado haber sido feliz. Todo un ejemplo de los tantos que se siguen malogrando en este, nuestro pobre y destruido país (véase "Quise ser escritor. Me hizo feliz. El adiós a Bernardo Kordon con un reportaje inédito”. Revista 3 Puntos 242 (Buenos Aires, 2002): 16 y ss. 
de Kordon le garantiza, entonces, un suelo narrativo casi único, un lenguaje directo, donde el lumpen se va volviendo lumpen sin que ningún reparo moral previo pueda juzgarlo. El texto de Kordon es una nouvelle de aprendizaje, donde a diferencia del bildungsroman clásico, el protagonista termina mal. Sin embargo, no podemos decir que hay un determinismo naturalista en el texto de Kordon, pero sí es posible asociar a su naturaleza (de “criollo”) y a su condición (la de “cabecita negra”) la degradación moral en la que va cayendo. La historia se ubica en la Buenos Aires posterior al peronismo clásico (1960), donde el desafío es vivir sin trabajar, ingresando a ese submundo de los artistas, la noche y el tango (Toribio abandona su casa para ser cantante de tangos en la radio. Al irse del mundo de su infancia-adolescencia, traiciona y roba a sus parientes y amigo). ${ }^{39}$ La Buenos Aires metrópolis genera esa alucinación. Toribio Torres se lanza a girar en derredor de esa luz, pero esa luz resulta ser la llama de una vela que termina por quemar sus alas. Y Lautaro Murúa percibe este sentido y logra — como siempre lo hace el buen cine—crear el clima en donde el espectador suspende sus prejuicios y deja que la historia fluya sobre sí. Fue tan fuerte el impacto que generó Alias Gardelito que tuvo que hacer frente a dos acusaciones de inmoralidad. Ambas denuncias no prosperaron, pero intimidaron a sus productores y exhibidores que la retiraron inmediatamente del mercado. La recepción del film fue ampliamente limitada y pese a ello, todo el país habló de la película.

\section{III.2.3. Operación Masacre - Operación Masacre}

Rodolfo Walsh es, a comienzos de 1956, un periodista que juega ajedrez y al que le gusta compartir sus noches en la ciudad de La Plata con gente que habla más "de Keres o Nimzovitch que de Aramburu y Rojas”. Sus experiencias literarias son con el policial y la literatura fantástica. ${ }^{40}$ Sin embargo, un tiroteo en enero de 1956 lo lleva a tomar contacto con la violencia política. La política se le mete en su vida. Se ve envuelto en un tiroteo y escucha morir, del otro lado de la ventana de su casa a un soldado. "Y ese hombre no dijo. 'Viva la patria', sino que dijo. 'no me dejen solo, hijos de puta'”. Se resiste a inmiscuirse. "Tengo demasiado para una sola noche. Valle no me interesa. Perón no interesa, la revolución no me interesa. ¿Puedo volver al ajedrez? Puedo. Al ajedrez y a la literatura fantástica que leo, a los cuentos policiales que escribo, a la novela 'seria' que planeo para dentro de unos años..." ${ }^{11}$ Sin embargo, "Hay un fusilado que vive”. Y ya nada será igual. Desde aquella noche de junio de 1956 hasta su muerte en manos de un "Grupo

\footnotetext{
${ }^{39}$ Pero esta traición es diferente a la de Silvio Astier en El juguete rabioso de Roberto Arlt (al modo de un Judas Iscariote, donde sí hay arrepentimiento). Aquí, Toribio no tiene ni el mínimo reparo moral, ni el mínimo sentido de la nobleza solidaria de clase. El lumpen emerge con toda sus dimensiones.

${ }^{40}$ En 1953 uno de sus relatos es seleccionado en el concurso de cuentos policiales de la revista Vea y Lea. El jurado estaba integrado por Leonidas Barletta, Jorge Luis Borges y Adolfo Bioy Casares. Para ese entonces, Walsh ya ha terminado su profesorado en Letras y trabaja como corrector, traductor y antólogo de la prestigiosa editorial y librería Hachette. De ese año 1953, también, es su primer libro de cuentos policiales Variaciones en rojo.

${ }^{41}$ Hasta aquí, todas las citas pertenecen al "Prólogo a la Tercera Edición" de Rodolfo Walsh, Operación Masacre, 19ª Edición.
} 
de Tareas” de la ESMA en marzo de 1977, la vida de Rodolfo Walsh no dejará de ser un remolino, que pasará, según aquella metáfora de David Viñas, del ajedrez a la guerra. De la representación simbólica de la guerra (en aquel café de La Plata, donde jugaba ajedrez) a la política armada (como miembro de Montoneros), de la pesquisa literaria (como autor de cuentos policiales) a la investigación periodística (en la investigación de los fusilados de José León Suárez).

Y es ese corte biográfico el que marca no sólo su literatura. Operación masacre se escribe así, en el estado de fascinación.

Es matador escuchar a Giunta, porque uno tiene la sensación de estar viendo una película que, desde que se rodó aquella noche, gira y gira dentro de su cabeza, sin poder parar nunca. Están todos los detalles, las caras, los focos, el campo, los menudos ruidos, el frío y el calor, la escapada entre las latas, y el olor a pólvora y a pánico... (Walsh 15)

Y cuando uno lee la novela entiende por qué está escrita como está escrita. Walsh se ve obligado a escribir con las claves de la ficción. La ficción del policial, la ficción del cine. Walsh necesita trasladar la película que tiene Giunta en su cabeza al papel. Necesita transmitir ese “Así me fusilaron” a la gente. Walsh no ha salido aún del mundo del ajedrez y de los policiales. Poco a poco ve que su historia no se la publica nadie, que debe dar vuelta por las redacciones, y que esa historia hace temblar a los dueños de los medios. Ese es el descubrimiento de Walsh, que la película de Giunta tiene alguna distancia con la película que puede ver la gente, que puede leer en los medios. ¿Dónde está — diría Slavoj •i•ek— esa "piedra de lo real” que tanto nos interpela? ¿Esa intolerable molestia? ¿Está más acá o más allá del arte, de la literatura? ¿Qué papel asumir?

Toda la vida y obra de Rodolfo Walsh parece contestar decididamente esa pregunta. Por eso cuando Jorge Cedrón decide trasponer la novela de Walsh al cine, no tiene que hacer mucho esfuerzo. El film está allí. Sólo alcanzaría con poner a Giunta frente a las cámaras y dejar que el celuloide copie la película que tiene en su cabeza. Pero Giunta no es el único sobreviviente. Está Livraga, que acepta asumir su rol y actuar. La película de Cedrón, entonces, es eso — un intento de restituir aquello que la literatura le había sacado al relato de Giunta.

José Cedrón ${ }^{42}$ venía como director de la experiencia de Realizadores de Mayo que unos años atrás, en 1969, había filmado doce capítulos de un intento mayor por representar la gesta popular conocida como el Cordobazo. El film se tituló Argentina, mayo de 1969; los caminos de la liberación..$^{43}$ Este film no fue estrenado comercialmente sino de manera clandestina. Aún hoy aparece en los catálogos como film inconcluso, pero en realidad y tal como ocurrió con muchas de las películas de aquellos años, su estrenoexhibición se hizo en sindicatos, bodegones, clubes y parroquias barriales o bien en reuniones de militantes y/o adherentes a la "resistencia peronista.” El grupo Realizadores de Mayo estaba integrado por Nemesio Juárez, Enrique Juárez, Humberto Ríos, Octavio

${ }^{42}$ Comienza su vida artística como actor en una película experimental y opera prima de Alberto Fischerman, The players vs Ángeles Caídos (1969) $84 \mathrm{~min}$. ${ }^{43} 210$ min. 12 capítulos. 
Getino, Pino Solanas, Jorge Martín, Eliseo Subiela, Pablo Szir, Rodolfo Jun y Jorge Cederrón. Esto marca muy a fuego la experiencia de Cedrón. Sin embargo, la opera prima de Cedrón será El habilitado (1971).${ }^{44}$ A propósito de esta obra, su autor define toda su concepción cinematográfica:

No van a encontrar en mi película esas vastas teorías sobre la realidad que construyen algunos cineastas a la francesa, quiero que encuentren la realidad (...) No una realidad generalizada, abstracta. (...) En mi película cabe más la estética de un Roberto Arlt, de un Beckett que los firuletes de algunos adictos a la nouvelle vague. (Un diccionario de films argentinos)

Interesante definición, ya que, como vemos, es diametralmente opuesta a la concepción de un Torre Nilsson o de un Lautaro Murúa, pero, paradójicamente, estos realizadores no pueden dejarse de vincular en ese proceso de elaboración cultural que el cine parece querer hacer de la literatura que lee. A medida que nos involucramos en los años setenta el realismo se convierte de una posibilidad de expresión narrativa de la Nación en una forma excluyente de representación (en el doble sentido del término: en tanto ilusión teatral de representar una historia o bien como intermediación política). Y Operación masacre $(1973)^{45}$ parece estar al final de ese camino. Nunca más contundente lo que dice su director cuando un periodista lo interroga:

— ¿Qué es lo importante en Operación masacre?

- Haber llegado a hacer una película que se inscribe en el marco del peronismo, es decir, hacer algo que está en el Pueblo, no meramente junto a él. (Jorge Cedrón a Carlos Mazar en Cine Liberación, Un diccionario de films argentinos)

La película de Cedrón encuentra entonces un tiempo y un debate que le son propicios, como nunca. La sociedad civil ha reforzado sus posiciones y la lucha política va desde lo ideológico-artístico hasta lo militar. Cedrón dice peronista como equivalente a pueblo, y pueblo aquí es sinónimo a sujeto de la revolución. La crítica lo ampara:

...lenguaje fílmico despojado de todo amaneramiento, con imágenes descarnadas (...) Cada uno de los personajes es definido con precisión. (Sin firma en La Opinión, Un diccionario de films argentinos)

Surge de una perspectiva revolucionaria combativa. Por esto trae una temática de una posición distinta. La necesidad de denunciar, discutir, conmover (Agustín Mahieu en La Opinión, Un diccionario de films argentinos)

\footnotetext{
${ }^{44} 78$ min. G. J.C. y Miguel Briante. Int. Héctor Alterio, Roberto Cedrón, Ana María Picchio, Walter Vidarte, José Ma. Gutiérrez y Alberto Quesada.

${ }^{45} 115$ min. Int. Norma Aleandro, Carlos Carella, José Ma. Gutiérrez, Víctor Laplace, Raúl Parini, ana María Picio, Fernando Iglesias, Jorge de la Riestra y Julio Troxler. Este último, sobreviviente de los fusilamientos. Troxler adhirió luego a Montoneros y desde 1976 integra la lista de desaparecidos por la dictadura militar.
} 


\section{Conclusión}

A esta altura de nuestro trabajo no nos queda mucho por decir. Creemos que sí es necesario, retomar el tópico central sobre el que hemos intentado vertebrar nuestro trabajo aquí. Y es que a lo largo del mismo, nos hemos preocupado por desarrollar y escenificar un conjunto de problemáticas en torno a las mediaciones culturales en la Argentina - las que se establecen entre los géneros literarios y la realidad, entre los géneros literarios entre sí, entre la literatura y la política, entre la literatura y el cine, entre la historia y la cultura.

Esas mediaciones no son un punto menor. Todo lo contrario, para nosotros ellas representan el vivo punto de interrogación de la vida material y cultural de nuestra sociedad. Es que vivimos un tiempo de colapsos. Todos aquellos puntos que constituían la sensación -diría Marshall Berman- de modernidad han caducado: el empleo, el progreso científico, la racionalidad, el placer estético. Es más, hasta la noción misma de Nación parece haber estallado bajo el ejido complejo del capitalismo global de cuño neoliberal, donde el retiro del Estado ha generado una sensación muy fuerte de desprotección, licuando aquellas instituciones que constituían la malla de contención social y que le daban a los sujetos la idea de ser ciudadanos. Ese desmoronamiento ha impuesto una tajante división entre consumidores y no-consumidores. Quien no está en el sistema perece... Pero el afuera crece en una distribución de la riqueza descomunal, donde la pirámide de población-riqueza es cada vez más abrupta. Y aquellas ideas que fundaron la Nación argentina perecen en la comunidad social: el trabajo es un privilegio de unos pocos, la salud es un bien perdido y la educación, gratuita y pública, es una ficción; el principio racionalizador de la Nación se ha vuelto espacio de reproducción de las condiciones sociales de dominación y marginación y no un espacio de esperanza.

Todo tipo de paradigma realista es hoy abominado por la mayoría de los escritores bienpensantes de la Argentina neoliberal. Escudados tras un antirrealismo estetizante, confunden autonomía del arte con evasión, olvidando que incluso el antirrealismo surgió como una necesidad histórica y política de repensar — más que de abolir — una relación, la que siempre existirá entre arte y realidad. Bioy Casares murió en este país como el último gran autor fantástico y muchos de los jóvenes narradores se declararon sus viudas. La mayoría lloraba al maestro con un tono de genuflexión increíble, básicamente, porque no le habían declarado toda la veneración que — según ellos- se merecía por sus ficciones o Planes de evasión. Lo cierto es que esos mismos escritores son los que alzaron sus voces para declarar la muerte del realismo y reclamar la independencia de la ficción de la realidad, de la literatura y todas las artes respecto a la historia. Y como bien ha señalado la escuela crítica (Adorno, Eagleton, Habermas), cada vez que se reclama una "vuelta a la estética (se) refuerza la ilusión de (una) libertad del individuo, propia de una necesidad (o sensibilidad) burguesa”. Y entonces, “el arte que se separa de las prácticas vitales — dice Jorge Yúdice - no puede pensar en la posibilidad de representar al 'otro' excepto para reprimirlo” (Masiello 28) (véase también Eagleton 50-51). 
BiBLiOgRAFÍA

Aguilar, Gonzalo Moisés. Lautaro Murúa. Serie "Los directores del cine argentino”. Buenos Aires: CEAL, 1994.

Anderson, Benedict. Comunidades imaginadas. Reflexión sobre el origen y la difusión del nacionalismo. Buenos Aires: FCE, 2000.

Barthes, Roland. "Escribir la lectura”. El susurro del lenguaje. Barcelona: Paidós, 1987. Beceyro, Raúl. Cine y Política. Ensayos sobre cine argentino. Santa Fe: UNL, 1997.

Benjamin, Walter. "La obra de arte en la época de su reproductibilidad técnica”. Discursos interrumpidos I. Madrid: Taurus, 1989

Capdevilla, Analí. "Una polémica olvidada. (Borges contra Caillois sobre el policial)”. Boletín/4, revista del Grupo de Estudio de Teoría Literaria (Rosario, Argentina, 1995).

Castañeda, Jorge. La utopía desarmada. Intrigas, dilemas y promesas de la izquierda en América latina. Buenos Aires: Ariel, 1994.

Cedola, Estela. Cómo el cine leyó a Borges. Buenos Aires: Edicial, 1999.

Couselo, Jorge Miguel (Comp.). Torre Nilsson por Torre Nilsson. Editorial Fraterna, 1985.

Couselo, Jorge Miguel et al. Historia del cine argentino. Buenos Aires: CEAL, 1992.

Crespo, Horacio. ”Poética, política, ruptura”. En la § Pensamiento, en Historia crítica de la literatura argentina (Noé Jitrik, Director). Vol. X “La irrupción de la crítica” (Susana Cela, directora del Volumen). Buenos Aires: Emecé, 1999.

De los Reyes, Aurelio. Medio siglo de cine mexicano. 1896-1947. México: Editorial Trillas, 1987.

Del Carril, Sara Luisa y Mercedes Rubio de Socchi. Borges en Sur. 1931-1980. Buenos Aires: Emecé, 1999.

Diaz, Claudio y Jimena Castillo (Comps.). “Dossier”. Revista Tramas, para leer la literatura argentina 1 (Córdoba, 1995).

Un diccionario de films argentinos. Buenos Aires: Corregidor, 1995.

Duarte, C. Lílian. “A (des)ordem internacional pelas lentes de Alfred Hitchcock". Comunicação \& Política 7/1 nova série (janeiro-abril 2000): 141-56.

Eagleton, Terry. Las ilusiones del posmodernismo. Buenos Aires: Paidós, 1997.

Eder, Klaus; et al. Buñuel Buenos Aires: Colección Kyrios, 1978.

Europe. Revue littéraire mensuelle. Année 78/859-860 (Paris, Novembre-Décembre 2000).

Felgine, Odile. “De l’américanité à la mediation. Roger Caillois et Victoria Ocampo”. Europe. Revue littéraire mensuelle. Année 78/859-860 (Paris, Novembre-Décembre 2000).

Ferro, Roberto (Investigación, selección y prólogo). Rodolfo Walsh. 'Yo también fui fusilado', 'Vuelve la secta del gatillo y la picana' y otros textos. Buenos Aires: GenteSur, 1990.

García Escudero, José María. Vamos a hablar de cine. Madrid: Salvat, 1970.

Gazzera, Carlos. “Borges/Sábato. Lecciones para la historia. (Los textos de una polémica)”. Cuadernos Hispanoamericanos 537 ( Madrid, marzo 1995): 21-38. 
Gran historia ilustrada del cine. Tomo 8. Madrid, 1984.

Grüner, Eudardo. El sitio de la mirada. Secretos de la mirada y silencios del arte. Buenos Aires: Norma, 2001.

Gubern, Román. Historia del cine. Lumen, 1997.

Historia universal de cine. Tomo I. Madrid: Planeta, 1982.

Kordon, Bernardo. Sus mejores cuentos porteños. Buenos Aires: Siglo XX, 1972.

Lacan, Jacques. Seminario 5. Las Formaciones del Incosciente. Buenos Aires: Paidós, 1999.

Lo Duca. Historia del cine. Buenos Aires: Eudeba, 1975.

Ludmer, Josefina. El cuerpo del delito. Un manual. Buenos Aires: Perfil Libros, 1999.

Manrupe, Raúl y María Alejandra Portella. Un diccionario de films argentinos. Buenos Aires: Corregidor, 1995.

Manvell, Roger. Film. Buenos Aires: Eudeba, 1964.

Martín, Mónica. El gran Babsy. Un hombre como yo no debe morir nunca. Biografía novelada de Leopoldo Torre Nilsson. Buenos Aires: Editorial Sudamericana, 1993.

Martínez, Carlos Dámaso. “Estudio preliminar” a Horacio Quiroga. Arte, lenguaje y cine. Buenos Aires: Losada, 1997.

Masiello, Francine. El arte de la transición. Buenos Aires: Editor Norma, 2001.

Olivera, Guillermo. "De la fotografía como arte al arte como fotografía”. ETC, Revista del Club Semiótico Año 6/7 (1995-1996).

Oszlak, Oscar. La formación del Estado Argentino. Orden, progreso y organización nacional. $3^{\text {a }}$ Edición. Buenos Aires: Planeta, 1999.

Panofsky, Erwin. Sobre el estilo. Tres ensayos inéditos. Irving Lavin, comp. Barcelona: Paidós, 2000.

Piglia, Ricardo. “Prólogo”. Las fieras. Antología del género policial argentino. Buenos Aires: Alfaguara, 1999.

Russo, Eduardo A. Diccionario del cine. Buenos Aires: El Amante-cine y Editorial Paidós, 1998.

Sarlo, Beatriz. La máquina cultural. Maestras, traductores y vanguardia. Buenos Aires: Ariel, 1998.

Slocum, David. "Film Violence and the Institutionalization of the cinema". Social Research 67/3 (Fall 2000).

Solanas, Fernando "Pino”. La mirada. Biografía de Sur. Buenos Aires: Puntosur, 1989. (Contiene una entrevista de Horacio González).

Sondereguer, María. “Avatares del nacionalismo”. En la § Pensamiento, en Historia crítica de la literatura argentina, (Noé Jitrik, Director). Volumen X “La irrupción de la crítica” (Susana Cela, directora del Volumen). Buenos Aires: Emecé, 1999.

Sorrentino, Fernando. Siete conversaciones con Jorge Luis Borges. Buenos Aires: El Ateneo, 1998.

Tarcus, Horacio. "El corpus marxista”. En la § Pensamiento, en Historia crítica de la literatura argentina, (Noé Jitrik Director). Volumen X "La irrupción de la crítica” (Susana Cela directora del Volumen). Buenos Aires: Emecé, 1999.

Vallejo, Gerardo. Un camino hacia el cine. Córdoba: El Cid Editor, 1984. 
Viñas, David. De Sarmiento a Cortázar. Literatura argentina y realidad política. Buenos Aires: Siglo XX, 1971.

Walsh, Rodolfo. Operación masacre. 19a edición. Buenos Aires: Ediciones de la Flor, 1994.

•i•ek, Slavoj. "Multiculturalismo o la lógica cultural del capitalismo multinacional”. Estudios Culturales. Reflexiones sobre multiculturalismo. Eduardo Grüner, comp. Buenos Aires: Paidós, 1998. 